\title{
МОВНА КАРТИНА СВІТУ ЯК ВІДОБРАЖЕННЯ РЕАЛЬНОСТІ
}

Живіцька I. А. Мовна картина світу як відображення реальності.

У статті розглядаються питання щодо мовної картини світу, аналізується історія поглядів стосовно цієї проблеми. Картина світу постає як світобачення кожної окремої людини й етносу загалом, як результат сприйняття та осмислення навколишнього світу, відображеного в мові.

Ключові слова: мовна картина світу, концептуалізація, пізнання, навколишній світ, світовідчуття, світорозуміння.

Живицкая И. А. Языковая картина мира как отражение реальности.

В статье рассматриваются вопросы, касающиеся языковой картины мира, анализируется история взглядов относительно этой проблемы. Картина мира предстает как миросозерцание каждого отдельного человека и этноса в целом, как результат восприятия и осмысления окружающего мира, который зафиксирован в языке.

Ключевые слова: языковая картина мира, концептуализация, познание, окружающий мир, мироощущение, миропонимание.

Zhyvytska I. A. The language picture of the world as a reflection of the reality.

The article deals with the questions which concern the language picture of the world, the history of views on this problem is analysed. The language picture appears as a contemplation of the world, as of an every single man, so as of the whole ethnic group. It is a result of the world's perception and comprehension which is kept in the language.

Key words: the language picture of the world, conceptualization, cognition, environment, sensation of the world, comprehension of the world.

Поняття картини світу (зокрема й мовної) грунтується на вивченні уявлень людини про світ. Картина світу - це результат обробки інформації про середовище і людину. Як глобальний образ, вона являє собою основу світобачення, світовідчуття і реалізується в різноманітних формах людської поведінки, до яких належить і людська мова. Сукупність уявлень про світ, зафіксованих у значенні різноманітних слів і висловів, формується в певну систему поглядів, які потребуть свого подальшого осмислення.

Мета нашої статті полягає в тому, щоб розкрити поняття «мовна картина світу», представити іiі як результат сприйняття та осмислення навколишнього світу, відображеного в мові.

Кожна мова, як відомо, відображає спосіб сприйняття i концептуалізацію світу тим чи тим етносом, що вирізняється своєю історією, культурою, своїми цінностями. Це, власне, і складає «національну модель світу», яка $є$ цілісним образом активності людини. Мова ж - найважливіший засіб формування і зберігання знань людини про об'єктивний світ, зафіксованих у слові. Сукупність цих знань, збережених у мовній формі, називається «мовною картиною світу» 
(В. Гумбольдт, Л. Вайсгербер, Е. Сепір, Б. Уорф, О. Потебня, В. Ужченко, Ю. Апресян, О. Кубрякова, 3. Попова, І. Стернін, В. Постовалова, I. Штерн, М. Кочерган та ін.).

Мовна картина світу є суб'єктивним образом об'єктивної реальності, оскільки кожна людина по-своєму і неповторно відтворює світ. Іншими словами, «мовна картина світу - це комплекс мовних засобів, у яких відображені особливості етнічного сприйняття світу», «це сукупність уявлень народу про дійсність, зафіксованих в одинцях мови на певному етапі розвитку народу» [6, с. 5]. Саме цим пояснюється те, що кожна національна мова - це універсальна система істин, знань і т. ін., зумовлена своєрідною психологією народу. Мова, через значення слова, представляє той чи той предмет об’єктивної картини світу, у сукупності ж концептуалізує ії. Мовна картина світу відображає у вербальних формах дійсність, яка сприймається свідомістю. Тому предметом дослідження сучасної лінгвістики $є$ питання «про ступінь впливу людини на мову, якою вона послуговується, і про вплив природної мови на поведінку і мислення людини, особливо у плані формування її картини світу» [5, с. 142].

Поняття картини світу бере початок від ідей В. фон Гумбольдта про внутрішню форму мови, 3 одного боку, і від ідей американської етнолінгвістики, зокрема гіпотези лінгвістичної відносності Сепіра Уорфа, - з іншого. В. Гумбольдт і його послідовники вважали, що в мова - «дух народу», вона приховує особливий світогляд і специфічний спосіб мислення. «Особливість духу і будова мови будь-якого народу, - зауважує науковець, - настільки внутрішньо пов'язані між собою, що одне передбачає інше. Мова є зовнішнім проявом духу народів. Мова - це їхній дух, а їхній дух - це їхня мова. Ніколи не вдасться належною мірою виявити їхню ідентичність [3, с. 147]. Він вбачав у мові силу, яка формує мислення народу. Мова сама створює образ, картину світу, а отже, відмінності в мовах породжуються відмінностями в поглядах на світ.

На основі вчення В. фон Гумбольдта відомий німецький дослідник Л. Вайсгербер розробив теорію мовної картини світу (Weltbild der Sprache). Терміном «картина світу» він послуговується вже у програмній монографії «Рідна мова і формування духу», яка була опублікована в 1929 році. Щоправда, учений витлумачує це поняття лише принагідно, здебільшого вказує на стимулюючу роль мови щодо формування в людини єдиної картини світу. Л. Вайсгербер писав: «Вона (мова) дозволяє людині об’єднати весь досвід у єдину картину світу і змушує ії забути про те, як раніше, до того, як вона вивчила мову, вона сприймала навколишній світ» $[1$, c. 51$]$.

У статті «Зв'язок між рідною мовою, мисленням і дією» (1930р.) Л. Вайсгербер уже безпосередньо «вписує» картину світу в саму мову, говорячи про неї як про фундаментальну ознаку. На його думку, словниковий склад конкретної мови містить у собі сукупність поняттєвих 
засобів мислення, які має у своєму розпорядженні мовна спільнота. I залежно від того, як кожен носій мови опановує цей словник, усі члени мовної спільноти оволодівають відповідними засобами мислення. А відтак «рідна мова відображає у своїх поняттях певну картину світу і передає іiі членам мовної спільноти» [9, с. 250].

Наукова еволюція Л. Вайсгербера стосовно концепції картини світу йшла в напрямку від вказівки на іiі об'єктивно-універсальну основу до підкреслення іiі суб’єктивно-національної природи. Він уявляв мову як певного «творця світу», залишаючи при цьому в тіні об'єктивний фактор формування картини світу - навколишній світ. Учений припускав, що існує відносна свобода людської свідомості від мовної картини світу, проте в іï межах. Інакше кажучи, від мовної картини світу, закріпленої у свідомості, ніхто звільнитися не може, але в межах самої цієї картини ми спроможні дозволити собі деякі «вольності», які i роблять нас індивідуальностями. Та своєрідність особистості, згідно 3 теорією науковця, завжди обмежена національною специфікою іiі мовної картини світу.

Визнаючи високий авторитет Л. Вайсгербера як автора вельми глибокої і детально розробленої концепції мовної картини світу, ми, як і багато інших сучасних учених, сприйняти ідею про те, що влада рідної мови над людиною абсолютно непереборна, не можемо. Не заперечуючи впливу мовної картини світу на мислення людини, необхідно водночас вказати на можливість невербального (немовного) шляху пізнання, коли не мова, а сам об'єкт впливає на напрям мислення.

Праці В. Гумбольдта та Л. Вайсгербера стали теоретичною основою і для відомої гіпотези лінгвістичної відносності Сепіра - Уорфа. Учені висунули тезу, що мова відіграє визначальну роль у процесі пізнання, а люди бачать світ по-різному - крізь призму рідної мови. Для прихильників цієї теорії реальний світ існує постільки, поскільки він відображається в мові. Однак, якщо кожна мова відображає дійсність властивим тільки їй способом, то, цілком закономірно, мови відрізняються своїми «мовними картинами світу».

Американський учений, етнолінгвіст Е. Сепір на основі деяких даних індійських мов намагався продемонструвати залежність культури народу від характеру його мови, уважаючи, що наше ставлення до навколишнього світу значною мірою залежить від мовних форм. Дослідник наводить безліч фактів, які підтверджують: мова повністю переплітається 3 безпосереднім досвідом людей. Помилковість гіпотези стосується передусім твердження: у процесі пізнання ніхто 3 нас не спроможний звільнитися від тиранії нашої мови: «Значення не стільки відкриваються в досвіді, скільки накладаються на нього через ту тиранічну владу, якою володіє мовна форма над нашою орієнтацією у світі» [11, с. 117]. Е. Сепір заперечував будь-які інші форми пізнання. 
Б. Уорф стверджував, що ми можемо по-різному бачити і сприймати світ, але саме мова визначає спосіб нашого бачення i сприйняття навколишнього світу. Він писав: «Ми розчленовуємо природу в напрямку, який підказує наша рідна мова» [13, с. 174]. Дослідник звертав увагу насамперед на класифікаційний бік мовної картини світу. Першочерговим завданням для нього було порівняти мовну картину світу з науковою. Як i в науці, на його думку, у мовній картині світу відображається класифікаційна позиція на світ. Причому, у різних мовах ця позиція представлена по-різному. Як наукова, так і мовна картини світу являють собою, згідно з Е. Уорфом, «систему аналізу навколишнього світу». Учений віддавав перевагу мовним картинам світу над науковими. Це i призвело його до ігнорування об'єктивним фактором пізнання внаслідок перебільшення значення мови для розвитку науки.

В обох випадках ми маємо справу з моделюванням світу. У цьому їхня схожість. Проте між ними є і суттєва відмінність: перша - результат діяльності вчених, друга - результат діяльності звичайних носіїв тієї чи тієї мови, які іiі і створили. Перша відображає наукову свідомість, друга повсякденну.

Ми впевнені, що пізнавальна діяльність людини може здійснюватися не тільки за допомогою мови, а й за їі межами - в абстракції від мовних форм. Мовні картини світу можуть виконувати лише допоміжну роль щодо науки, але вони не спроможні претендувати на провідну роль стосовно наукових картин світу. Мовні картини світу не можуть бути основним джерелом наукових знань, бо таким джерелом, насправді, є і завжди була об’єктивна дійсність.

Серед перших, хто продовжив розбудовувати теорію В. фон Гумбольдта, був О. Потебня, який репрезентував свою філософію мови. Вітчизняний науковець убачав у мові механізм, що породжує думку: «Слово, узяте загалом, як сукупність внутрішньої форми і звука, $\epsilon$ передусім засобом розуміння мовця, аперцепції змісту його думки. Членороздільний звук, що його породжує мовець, сприймається слухачем, асоціаціюється 3 відомими йому звуками і за допомогою внутрішньої форми викликає у свідомості думку про сам предмет» [8, с. 123]. Семасіологічне вчення О. Потебні зосереджене навколо слова як засобу аперцепції (сприйняття) думки. Власну концепцію інтерпретації лінгвофілософської категорії «мовна картина світу» створив В. Жайворонок. У мовній картини світу вчений вбачає «усе те, що йде передусім від людини або етносу, результат людського сприйняття, фантазій, мисленнєвих процесів і перетворювальної діяльності» [4, с. 9]. Дослідник упевнений, що всесвіт $є$ предметом пізнання, тому, осмислюючи його, людина пізнає і саму себе, оскільки іï внутрішній, суб'єктивний світ є відображенням світу зовнішнього, об'єктивного. I в 
цьому процесі важливим елементом $є$ мова, а відтак феномен світу, пізнаного через мову, постає для людини образами їі мови [4, с. 9-10].

Під категорією «мовна картина світу» В. Ужченко розуміє «вербалізовані інтерпретації мовними соціумами навколишнього світу й самих себе в цьому світі» [12, с. 67]. Він констатує, що картина світу $є$ власне світобаченням як кожної окремої людини, так і етносу загалом, вона $\epsilon$ результатом сприйняття та осмислення навколишнього світу, зафіксованого в мові. Унаслідок процесів узаємодії людини 3 реальним світом виникає неперервний зв'язок між людиною, всесвітом та ії мовою, де всі елементи взаємопов'язані [12, с. 67-68].

Схожу думку має I. Голубовська, яка визначає мовну картину світу як «виражене засобами певної мови світовідчуття та світорозуміння етносу, вербалізовану інтерпретацію мовним соціумом навколишнього світу і себе в цьому світі» [2, с. 6]. Ця дослідниця розрізняє концептуальну і мовну картини світу, наголошуючи на тому, що для останньої характерне повсякденне, наївне відображення реальності, на противагу науковості та загальнолюдському характеру концептуальної картини світу [2, с. 38].

О. Селіванова виокремлює таке поняття, як «ментальний лексикон мови», що характеризує не свідомість окремого мовця, а інтерпретацію реального світу свідомістю цілого народу, який є носієм тієї чи тієї мови $[10$, с. 84$]$.

3 думками цих учених важко не погодитися, оскільки людина, що живе в соціумі, послуговується мовою не може бути ізольованою і стояти осторонь тих процесів, які відбуваються в суспільстві. Вона постійно взаємодіє із навколишнім світом, відчуває його вплив і сама впливає на його розвиток.

Картина світу, безумовно, $\epsilon$ національно забарвленою, адже інтерпретується, пропускаючись крізь призму національного світобачення та світорозуміння. В. Постовалова вважає, що «картина світу», звичайно ж, не «дзеркальне відображення світу і не відкрите «вікно» у світ, а саме картина, тобто інтерпретація, акт світорозуміння... вона залежить від призми, через яку здійснюється світобачення» [7, с. 24].

А отже, поняття «мовна картина світу» пов'язане 3 поняттями народ, етнос, нація і розумінням національного характеру.

\section{Лiтература}

1. Вайсгербер Й. Родной язык и формирование Духа / Вайсгербер Йоханн Лео. M., 2004. - 232 c.

2. Голубовская И. А. Этнические особенности языковых картин мира / И. А. Голубовская. - К. : ВПЦ «Київський ун-т», 2002. - 293 с.

3. Гумбольдт В. фон. Избранные труды по языкознанию / Вильгельм фон Гумбольдт; [пер. с нем. Г. М. Рамишвили]. - М. : Прогресс, 1984. - 397 с.

4. Жайворонок В. В. Українська етнолінгвістика : нариси / В. В. Жайворонок. К. : Довіра, 2007. - 263 с. 
5. Кубрякова Е. С. Роль словообразования в формировании языковой картины мира / Е. С. Кубрякова // Роль человеческого фактора в языке : Язык и картина мира. - М. : Наука, 1988. - С. 142-172.

6. Попова 3. Д. Язык и национальная картина мира / 3. Попова, И. Стернин. Воронеж : Истоки, 2002. - С. 5-16.

7. Постовалова В. И. Картина мира в жизнедеятельности человека // Роль человеческого фактора в языке : Язык и картина мира / В. И. Постовалова. М. : Наука, 1988. - 215 с.

8. Потебня А. А. Слово и миф / А. А. Потебня. - М. : Правда, 1989. - 624 с.

9. Радченко О. А. Язык как миросозидание. Лингвофилософская концепция неогумбольдтианства / О. А. Радченко. - М., 2006. - 312 с.

10. Селіванова О. О. Актуальні напрямки сучасної лінгвістики (аналітичний огляд) / О. О. Селіванова. - К. : Фітосоціоцентр, 1999. - 148 с.

11. Сепир Э. Избранные труды по языкознанию и культурологии / Эдуард Сепир; [пер. с англ. ; под ред. А. Е. Кибрика]. - М. : Наука, 1993. - 656 с.

12. Ужченко В. Д. Актуальні питання розвитку української мови : [посібник для магістрантів] / В. Д. Ужченко. - Луганськ : Альма-матер, 2005. - 146 с.

13. Уорф Б. Отношение норм поведения и мышления к языку / Б. Уорф // Новое в зарубежной лингвистике. - Вып.1. - М. : Иностранная литература, 1960. С. $145-178$. 